\title{
A Política Econômica nos Anos 1930: Evidências de uma Heterodoxia Consciente
}

\section{The Economic Policy in the 1930's: Evidences of a Conscious Heterodoxy}

\author{
Marcio Alvarenga Junior* \\ Fernando Augusto Mansor de Mattos**
}

\begin{abstract}
Resumo: O presente trabalho tem por finalidade discutir alguns aspectos da política anticíclica para a superação da crise de 1929, incluindo as escolhas técnicas em resposta à depressão econômica, o caráter político ideológico das medidas utilizadas e, por fim, a própria intencionalidade na condução dessas políticas como transformadoras da ordem econômica, revelando como tais políticas passaram a dialogar com novas vias de desenvolvimento na época. A partir do uso e análise de dados oficiais disponibilizados pelo Ipeadata e pelo Anuário Estatístico do Brasil de 1939/40 publicado pelo Instituto Brasileiro de Geografia e Estatística (IBGE), os autores calculam o multiplicador monetário da época, cujos valores parecem reforçar a hipótese sustentada por este artigo de que a condução da política econômica foi feita de forma heterodoxa e intencional, tendo o governo e, principalmente, Vargas, consciência do papel dessas medidas tanto para superação da crise, quanto para a consolidação dos novos pactos políticos que se estabeleceram no bojo do poder a partir da Revolução de 1930.
\end{abstract}

Palavras-chave: Ortodoxia e heterodoxia. Indústria brasileira nos anos 30. Revolução de 1930 no Brasil. Intencionalidade da política econômica. Política creditícia.

\begin{abstract}
This paper aims to discuss some aspects of countercyclical macroeconomic policy to overcome the Great Depression, including the technical choices in response to the crisis, the political and ideological orientation behind the set of macroeconomic policies implemented during the 1930' years, and finally, the intentionality on handling these policies in order to remodeling the Brazilian economic structure, revealing how these policies were related to new modes of development at that time. Using official data, provided by Ipeadata and Anuário Estatístico do Brasil de 1939/40 - published by Brazilian Institute of Geography and Statistics (IBGE) - the authors calculated the money multiplier, which values seems to reinforce the hypotheses held by this article, which states that the set of policies implemented in the 1930s years was intentionally designed in a heterodox way not only to rescue the economy, but also to support the political pacts signed during the 1930 Revolution.
\end{abstract}

Keywords: Orthodoxy and heterodoxy during Vargas' presidential term. Brazilian industry. Revolution of 1930 in Brazil. Intentionality of economic policy. Credit policy.

\footnotetext{
* $\quad$ Economista graduado pela Universidade Federal do Rio de Janeiro (UFRJ). Mestre em Economia pela Universidade Federal Fluminense (UFF). E-mail: marcio.alvarenga.junior@gmail.com

** Doutor e Mestre em Economia pelo Instituto de Economia da UNICAMP. Professor e pesquisador do Programa de Pós-Graduação em Economia da Universidade Federal Fluminense (UFF). E-mail: fermatt1@hotmail.com
} 
JEL Classification: N16; O14.

\section{Introdução}

Os anos 1920 representaram o período de mais intenso crescimento econômico da República Velha. ${ }^{1}$ Esse crescimento, embora bastante heterogeneamente distribuído ao longo da década, ${ }^{2}$ foi liderado basicamente pela expansão das atividades industriais no país (FAUSTO, 2006c). Em boa medida, os momentos de êxito do crescimento do PIB e da atividade industrial coincidiram com os programas mais exitosos de valorização do café - os quais, por sua vez, tiveram seu sucesso viabilizado especialmente em momentos de expansão da liquidez do sistema financeiro internacional (FRANCO; LAGO, 2012). Não foram, porém, pouco conflituosos esses programas de defesa do café, rebatendo em contendas federativas que acabaram exacerbando rivalidades regionais e setoriais no período, situação que teria desdobramentos ainda durante a década de 1930 (FAUSTO, 2006a). Não por acaso, as disputas eleitorais dos anos 1920 foram marcadas por resultados muito mais acirrados do que os apresentados nos primeiros trinta anos da República Velha (FAUSTO, 2011; KOIFMAN, 2002).

Esse acirramento dos conflitos federativos representou uma face da elevada concentração regional que marcou o crescimento industrial do período, ${ }^{3}$ e decorria também do fato de que o café representava parcela amplamente majoritária na pauta exportadora brasileira, em contexto também de elevada participação do país na oferta mundial do café. Tal situação, se, por um lado, justificava ${ }^{4}$ uma política específica para a sustentação do preço do café, por outro lado abria precedente para que produtores de outros gêneros agrícolas também demandassem do governo federal um tratamento especial (FAUSTO, 2006a).

A expansão industrial promoveu importantes mudanças na ordem econômica e social, sendo a urbanização um aspecto importante dessas transformações. Foi nesse contexto que se deu o robustecimento de diversos segmentos que a literatura denomina genericamente de classes médias, como os militares e os cada vez mais numerosos profissionais do setor privado (e também os do setor público), que passaram a clamar por maior participação política e social. No mesmo sentido, também a burguesia industrial passou a exigir maior participação na definição das regras de política econômica e de decisões acerca do direcionamento dos

$1 \quad$ Ver Fritsch (1990)

2 Ver Suzigan (1975).

3 Sobre os condicionantes e características desse processo de desenvolvimento industrial fortemente concentrado regionalmente, ver o clássico trabalho de Cano (1975).

$4 \quad$ E também a permitia, exatamente pelo fato de que o Brasil detinha cerca de $65 \%$ a $70 \%$ do total da produção mundial do produto, podendo, assim, manipular seu preço internacional através de políticas de retenção de estoques. Sobre esse mecanismo, ver, além do clássico trabalho de Furtado (1959), também Delfim Netto (2009) e Fritsch (1990). 
gastos públicos. O surgimento (e/ou expansão) dessas novas classes sociais, ao lado da crescente rebelião das oligarquias agrárias regionais, ${ }^{5}$ explica o novo arco de alianças políticas que, em novembro de 1930, levaria ao poder Getúlio Dornelles Vargas e sua Aliança Liberal. A Revolução de 1930, portanto, representou uma nova era, em que a condução da política econômica não mais poderia contemplar apenas os interesses da burguesia cafeeira, liderança inconteste de uma economia primário-exportadora (FAUSTO, 1997). Após 1930, tanto por causa da mudança do cenário externo, quanto também em virtude das alterações que a diversificação produtiva, em curso pelo menos meados dos anos 1920, havia causado no cenário de forças políticas e sociais internas, a política econômica passaria a contemplar, primordialmente, o objetivo de sustentação e depois de recuperação do mercado interno da economia brasileira, numa mudança que Furtado resume muito adequadamente na expressão "deslocamento do centro dinâmico", com a qual batizou o capítulo 32 de Formação Econômica do Brasil (FURTADO, 1959).

O principal objetivo deste artigo é discutir a intencionalidade, em favor da diversificação produtiva (e, em especial, da industrialização), das medidas tomadas em resposta aos desdobramentos econômicos e políticos da crise deflagrada em 1929. Para tanto, pretende-se avaliar as teses de Furtado sobre a natureza da recuperação da economia brasileira no período pós-1930, expostas em seu livro célebre, Formação Econômica do Brasil (doravante, FEB), que suscitaram (e ainda provocam) intenso debate a respeito dos efeitos que as políticas fiscal, monetária, creditícia e cambial tiveram sobre a retomada do crescimento da economia brasileira e, em especial, da produção industrial. Neste artigo, as medidas de política econômica se inserem dentro do que chamaremos de medidas de caráter institucional $^{6}$ tomadas em apoio à intencionalidade industrializante do novo governo que se instalara em outubro de 1930.

5 Um detalhe que merece registro é que nem todas as atividades agropecuárias eram destinadas à exportação, dependendo mais do aquecimento do mercado interno do que da demanda externa, como, por exemplo, o caso do charque e do mate gaúcho e da produção pecuária nordestina, entre outros produtos. Isso explica porque as oligarquias regionais apoiavam uma política econômica voltada para a sustentação da renda interna da economia brasileira. Na mesma esteira, é interessante destacar que a parcela da elite paulista que desde sempre esteve em oposição a Getúlio Vargas foi a elite cafeeira. A burguesia industrial paulista, em parte, esteve sempre ao lado de Vargas, e outra parcela aderiu depois (Cf. LOVE, 1997; CANO, 1975).

6 Fonseca (2003) destaca que existem pelo menos três formas de se avaliar o conteúdo do conceito de "instituição", devido à evolução que as ideias institucionalistas vêm tendo desde a contribuição inovadora de Veblen, ainda no século XIX. Neste artigo, o que se entende por instituição se assemelha - embora não de forma rígida - à definição proposta por Fonseca (2003), segundo a qual a delimitação do termo "[...] se assenta em uma definição de natureza mais histórica, associando instituição a estruturas, organizações ou conjunto de leis, abarcando, portanto, por exemplo, a moeda, o sistema jurídico, as corporações, o sistema financeiro e os organismos econômicos internacionais" (FONSECA, 2003, p. 135). As outras concepções do conceito de instituição derivam ou da antiga tradição que a relaciona a um amplo leque de valores, como cultura, símbolos e outros elementos sociológicos, ou, então, mais restritamente, à escola neoclássica da Nova Economia Institucional, que, basicamente, associa o conceito a fatores relacionados ao 
Dando continuidade ao esforço de conferir maior precisão aos termos aqui tratados, torna-se essencial dizer que a heterodoxia surge neste artigo como um conceito bidimensional. Em seu aspecto econômico, revela a utilização continuada de uma política anticíclica ao longo da década de 1930. Em sua face política, remete ao fato de que esse conjunto de medidas de política econômica atendeu a um projeto específico que tinha na diversificação produtiva a contrapartida do apoio recebido por outros setores da economia e classes sociais, frequentemente marginalizados dos cálculos políticos antes da ascensão de Vargas ao poder. Portanto, deve-se sublinhar que não faria sentido discutir intencionalidade industrializante se não se avaliasse como heterodoxa a política econômica praticada por Vargas, sobretudo porque este enxergava na diversificação da estrutura produtiva e na endogeneização do processo de acumulação (ou, em termos equivalentes: no "deslocamento do centro dinâmico" da economia) as alternativas para enfrentar os efeitos econômicos da própria crise e solidificar novas alianças políticas.

Em apoio ao argumento segundo o qual houve uma intencionalidade heterodoxa da política econômica, este artigo calcula multiplicadores monetários para o período analisado (1930-1939). Esse indicador foi obtido a partir de dados referentes aos agregados monetários disponibilizados pelo Ipeadata e pelo Anuário Estatístico do Brasil de 1939/40 publicado pelo IBGE. Os valores obtidos revelam que a condução da política monetária seguiu uma trajetória condizente com as necessidades econômicas e políticas citadas anteriormente.

A estrutura deste artigo encontra-se dividida em duas seções, além desta introdução. Na primeira seção, é apresentado o debate sobre os determinantes para a superação precoce da crise econômica no caso brasileiro. Na segunda seção, em uma primeira parte, é apresentado o modelo de ajuste a crises econômicas praticado no Brasil antes de 1930, geralmente em resposta a contrações na liquidez externa ou do comércio internacional. Essa subseção serve de insumo no esforço empreendido neste trabalho com vistas a demonstrar uma ruptura na condução da política econômica. Na última parte da segunda seção, o caráter anticíclico da política econômica praticada pelo governo Vargas é enfatizado, buscando-se fornecer evidências de que o conjunto de políticas implementadas em resposta à crise seguiu uma orientação conscientemente heterodoxa, em favor do projeto de industrialização. Os argumentos para defender essa tese repousam na análise de dados econômicos e também de instituições criadas pós-1930. Nas considerações

institucionalismo da microeconomia tradicional. Na verdade, esses conceitos nem sempre são excludentes, mas, de todo modo, o importante é destacar que, neste artigo, se considera como instituições tanto os elementos constitutivos das chamadas políticas instrumentais (política monetária, creditícia, cambial, etc., ou seja, os diversos aspectos do que se convenciona considerar como partes da política econômica), quanto também órgãos, ministérios, autarquias, etc. criados, sem olvidar também das medidas e leis de regulação social (embora estas últimas não sejam discutidas em profundidade). 
finais, são reunidos os principais argumentos para defender a ideia de que as ações estatais pós-1930 tiveram intencionalidade industrializante.

\section{Debate Sobre a Reorientação do Receituário de Política Econômica Diante da Crise de 1930}

A tese seminal de Furtado (1959) sustenta que a recuperação precoce da economia brasileira na década de 1930 deveu-se aos impactos sistêmicos não previstos do gasto com a política de defesa do setor cafeeiro sobre a demanda agregada. Em paralelo, a desvalorização cambial, ocorrida inicialmente ${ }^{7}$ como decorrência da vultosa fuga de capitais ${ }^{8}$ e da contração do comércio internacional, bem como o posterior controle de importações - ambos deflagrados em função do crítico cenário de restrição externa que se inaugurou com a crise de 1929 - acabaram revelando-se funcionais para redirecionar o centro dinâmico da economia do país para o mercado interno. Nesse contexto, a dramática redução na capacidade de importar - que, segundo Abreu (1990), reduziu-se em 40\% entre 1928 e 1932 terminou represando a demanda agregada nos limites do mercado doméstico, de modo que uma série de produtos que antes eram obtidos via importação passaram a ser substituídos pela produção da indústria brasileira.

Por sua vez, a sustentação da procura agregada em um contexto declinante da capacidade de importar questionava a capacidade da indústria nacional em atender à demanda então represada. De acordo com Furtado (1959), dois fatores foram decisivos para que a indústria nacional pudesse atender a essa reorientação da procura agregada: a existência de capacidade ociosa nas firmas no início da década de 1930 e a possibilidade de aquisição de máquinas e equipamentos a preços muito baixos em função da onda de falências no exterior. Nesse período, são emblemáticos os casos, respectivamente, das indústrias de ferro, aço e cimento, que viram sua produção aumentar em 60\% entre 1929 e 1932, em virtude do aumento da procura por bens de capital (FURTADO, 1959, p. 199).

Em relação à crise que assolou o setor cafeeiro, Furtado (1959) chamou atenção para o fato de que era também possível encontrar explicações para a ocorrência desse fenômeno no lado da oferta, além dos fatores relacionados à demanda pelo produto. O Brasil, ao se utilizar de seu poder de monopólio no mercado para

7 Posteriormente, a política econômica adotada, ao invés de tentar fazer uma política de contenção de gastos públicos (de caráter ortodoxo, portanto), na tentativa de manter a paridade cambial mesmo diante de crises externas, como foi feito em tantos momentos anteriores ao longo do período republicano e também nas últimas décadas do período monárquico (o padrão ouro-libra foi adotado em 1846, no Brasil), o governo revolucionário de Vargas optou por adotar uma política creditícia expansionista, que acabou sancionando a desvalorização cambial, que já se encontrava em curso desde pelo menos o final de 1929.

8 A fuga de capitais também foi viabilizada pelo fato de a conta de capitais ser aberta - parte integrante do mecanismo de funcionamento do padrão ouro-libra. 
sustentar, quase por três décadas, o preço do grão em patamares artificialmente elevados, gerou uma trajetória de descasamento entre a oferta e demanda de café ao longo do tempo, em favor da superprodução. Outros três fatores merecem destaque na tendência à superprodução nesse mercado, a saber: a) a disponibilidade de mão de obra; b) a disponibilidade de terras subocupadas; e c) a pouca opção para inversões de capital em outros setores. Assim Furtado (1959) sintetizou a crise no setor:

\begin{abstract}
A grande acumulação de estoques de 1929, a rápida liquidação das reservas metálicas brasileiras e as precárias perspectivas de financiamento das grandes safras previstas para o futuro, aceleraram a queda no preço internacional do café iniciada conjuntamente com a de todos os produtos primários em fins de 1929. Essa queda assumiu proporções catastróficas, pois, de setembro de 1929 a esse mesmo mês de 1931, a baixa foi de 22,5 centavos de dólar por libra para 8 centavos. Dadas as características da procura do café, cujo consumo não baixa durante as depressões nos países de elevadas rendas, essa tremenda redução nos preços teria sido inconcebível sem a situação especial que havia se criado do lado da oferta. Basta ter em conta que o preço médio pago pelo consumidor norte-americano, entre 1929 e 1931, baixou apenas de 47,9 para 32,8 centavos por libra. Acumularam-se, portanto, os efeitos de duas crises: uma do lado da procura e outra do lado da oferta. A situação favoreceu as organizações intermediárias no comércio do café, as quais, percebendo a debilidade da posição da oferta, puderam transferir para os produtores brasileiros grande parte de suas perdas causadas pela crise geral. (FURTADO, 1959, p. 187).
\end{abstract}

O autor ainda atenta para o fato de que, embora a desvalorização do mil-réis tenha sido antes fruto do contexto externo extremamente adverso, econômica e financeiramente, do que propriamente de uma política deliberadamente desenvolvimentista, seu resultado foi a suavização da queda no preço internacional do café quando contado em moeda doméstica. Em suas palavras: “[...] o valor médio da saca de café exportada declinou de 4,71 libras em 1929, para 1,80 libras em 1932-34, ou seja, uma baixa de 62\%. Em moeda nacional a queda foi de 192 para 145 mil-réis, isto é, 25 por cento". (FURTADO, 1959, p. 187). Desse modo, não foi apenas a queima do estoque de café que serviu para atenuar os efeitos da crise. A própria desvalorização cambial também se ocupou do arrefecimento da queda da renda cafeeira e, consequentemente, do nível interno de atividade.

Em relação à parte deliberada das medidas, isto é, a política de defesa do setor cafeeiro, Furtado (1959) chama atenção para o seu caráter essencialmente heterodoxo. É bem verdade que políticas de sustentação da renda cafeeira há muito eram implementadas. Deve-se destacar, contudo, tal qual afirma o autor, que seu financiamento anterior à década de 1930 era fundamentalmente baseado na obtenção de empréstimos externos. Com a retração do comércio mundial, em 
função da crise econômica, e com o progressivo estancamento do fluxo de capitais externos, em virtude da desestruturação do sistema financeiro internacional, tornou-se cada vez mais difícil negociar recursos para financiar a sustentação do preço do café. A partir de 1929, ante a necessidade ainda mais premente - e de maiores dimensões - de continuar mantendo políticas de controle de oferta de café, o Brasil terminou optando por uma solução doméstica: a expansão monetária e creditícia, com papel de destaque para o Banco do Brasil, para financiar, entre outras coisas, os déficits públicos em função da aquisição do café para sua posterior destruição. Tais medidas, segundo Furtado, em muito se assemelhavam na prática ao que viria a ser conhecido alguns anos depois como o receituário anticíclico keynesiano. A respeito do caráter distinto entre as políticas de defesa do setor cafeeiro, antes e depois de 1930, Furtado (1959) afirma:

A acumulação de estoques de café realizada antes da crise tinha sua contrapartida em débito contraído no exterior. Não existia, portanto, nenhuma inversão líquida, pois o que se invertia dentro do país, acumulando estoques, se desinvertia no exterior contraindo dívidas. [...] O mesmo não ocorria à acumulação de estoques financiada de dentro do país, se a base deste financiamento era uma expansão de crédito. A compra do café para acumular representava uma criação de renda que se adicionava à renda criada pelos gastos dos consumidores e dos inversionistas. (FURTADO, 1959, p. 194).

Contrariando a tese furtadiana, Peláez (1971) alega que o apego à ortodoxia por parte do governo provisório foi muito mais forte do que o suposto em FEB. Para chegar a essa conclusão, o autor se utilizou de uma série de discursos dos policymakers da época em favor do controle inflacionário e do equilíbrio fiscal, entre outras medidas do receituário ortodoxo de enfrentamento de crises, além de apontar para o papel de fato exercido pela taxação da exportação de café enquanto mecanismo de financiamento de seu programa de defesa. Em relação à condução da política macroeconômica na década de 1930, analisando o Anuário Estatístico do Brasil de 1939/40 publicado pelo IBGE, Peláez (1971) defende a presença de um caráter ortodoxo condizente com o discurso das autoridades do governo provisório, salvo em 1932, quando se verificou um elevado déficit por ocasião da Revolução Constitucionalista paulista e dos gastos com a seca no nordeste. No que tange à recuperação da economia brasileira, o autor afirmou que se deu em grande medida em função do excepcional resultado do balanço comercial, e não pela substituição de importações em curso, que direcionou, segundo Furtado, uma parcela maior da demanda agregada para o mercado interno. ${ }^{9}$

9 Em relação ao caráter heterodoxo das políticas macroeconômicas praticadas em resposta à crise, Peláez (1971) afirma que "[...] o crescimento das despesas, financiado por impostos novos, não corresponde à política fiscal Keynesiana” e, ainda, “[...] os créditos do Banco do Brasil e do tesouro nacional não podem ser considerados, estritamente falando, criação de moeda, pois foram 
Após as interpretações de Furtado (1959) e de Peláez (1971), uma série de outros autores passaram a participar do debate acerca da natureza das políticas implementadas, debruçando-se sobre os determinantes para a superação precoce da crise, bem como sobre os aspectos políticos e ideológicos das medidas postas em prática.

Silber (1977), por exemplo, alega que o peso dos impostos sobre a exportação de café como fonte financiadora do programa de defesa do setor cafeeiro foi menor do que afirma Peláez em sua obra. Enquanto Peláez (1971) postula que cerca de $60 \%$ do programa foi financiado via impostos entre maio de 1931 e abril de 1932, tendo esse percentual se elevado para cerca de 66\% entre abril de $1932 \mathrm{e}$ fevereiro de 1933, Silber afirma que a partir desta data até o final do ano de 1934 não mais do que a metade do que fora gasto com a defesa dos preços do café encontrou financiamento na tributação. Na mesma linha de argumentação, Franco (1985) revela que a parte não financiada por impostos no período que vai de 1931 a 1933 transitou entre 3,3\% e 5,5\% da renda interna, enquanto, a partir de fevereiro deste último ano até dezembro de 1934, tal parte atingiu um valor entre $10 \% \mathrm{e}$ $20 \%$ da renda nacional. Além disso, dada a inelasticidade-preço da demanda por café, Silber argumenta que uma parcela considerável dos impostos foi transferida aos consumidores externos, não representando, portanto, uma taxação da renda doméstica - tese também defendida por Fishlow (1972). Nesse sentido, é possível afirmar que a expansão dos gastos do governo, mesmo que financiada por taxação, teve um impacto positivo sobre o nível de produto, sobretudo considerando a própria afirmação de Peláez de que os impostos não foram suficientes para financiar por completo o programa de defesa do café, conforme também salienta Abreu (1990).

Em relação à condução da política monetária e creditícia, Silber (1977) ainda afirma que a mesma esteve longe de servir a práticas ortodoxas. Analisando uma nova série de dados, o autor atenta para o fato de os meios de pagamento terem crescido continuamente entre 1930-1939 - excluindo apenas o ano de 1933 -, chegando, no final do período, a um valor duas vezes maior do que o valor inicialmente observado. As razões apontadas por Silber para a vertiginosa elevação em M1 vão desde créditos concedidos pelo Banco do Brasil (incluindo a reestruturação de sua carteira de redescontos), emissões do Tesouro Nacional com o fito de financiar o programa de defesa do setor cafeeiro, até à necessidade de financiar elevados déficits no início da década, que, ante a retração dos recursos orçamentários (haja vista a queda do montante arrecadado em função da queda das importações), valeu-se do recurso à emissão monetária. Em suma, segundo Silber (1977), a política monetária pós-crise teve uma trajetória coerente com a necessidade de expansão dos gastos, sendo comumente utilizada para financiá-la.

pagos com as receitas mensais proveniente das exportações” (PELÁEZ, 1971, p. 95). 
De maneira sintética, pode-se argumentar que, de um lado, Furtado apresentou uma tese de ampla aceitação sobre a importância da política de defesa dos preços do café enquanto gasto para a sustentação da renda nacional. Por outro lado, Peláez também contribuiu decisivamente para o debate ao indicar a relevância dos impostos sobre a exportação do café como um dos meios utilizados para financiar tais políticas, muito embora pareça ter se equivocado no peso excessivo que deu a essa forma de taxação. Outro aparente equívoco cometido por Peláez reside na sua tentativa de rotular de ortodoxas as políticas macroeconômicas reativas à crise, tendo esse esforço sido amplamente influenciado pelos discursos dos policymakers da época. Por fim, as próprias razões apresentadas pelo autor para a rápida recuperação da economia brasileira, ancoradas no resultado "excepcional" da balança comercial brasileira, ${ }^{10}$ também pecam por certa falta de realismo. Nesse sentido, o autor parece esquecer, ou ao menos fazer pouco caso da dramática inflexão da economia mundial, da ruína do padrão ouro - ou seja, da retração e desestruturação do comércio internacional e do sistema financeiro global - e de seus efeitos em termos de ampliação do raio de manobra para a execução de uma política econômica mais condizente com a necessidade de recuperação da atividade econômica interna, depois de passados os efeitos mais imediatos e desestruturantes promovidos pela deflagração da própria crise.

\section{Inconsciência ou Intencionalidade: um Breve Debate Sobre os Condicio- nantes Políticos e Econômicos da Macroeconomia na Década de 1930}

Outro debate fundado pela principal obra de Furtado diz respeito à existência ou não de intencionalidade por parte dos formuladores e executores políticos na década de 1930 no que tange à reorientação da estrutura produtiva brasileira em favor da indústria. Em FEB, Furtado alega que o deslocamento do "centro dinâmico" da economia brasileira das exportações de produtos primários para a atividade industrial foi um subproduto da política de defesa do café, não tendo esta respondido a qualquer consciência decisória, mas sim ao pragmatismo dos novos governantes em um contexto profundamente crítico. Isto é, foi a urgência da situação que se colocara à época que determinou uma atuação dos formuladores e executores políticos diferente daquelas recomendadas pela concepção ortodoxa, inexistindo, portanto, qualquer plano, programa, ou desejo que pudesse ter ancorado as transformações vividas pela sociedade brasileira na década. Em uma passagem bastante emblemática, Furtado (1980) alega que:

10 Na verdade, a ocorrência de elevado superávit comercial decorreu muito mais de uma retração nas importações do que em suposta expansão das exportações. O cenário externo excepcionalmente ruim explica esse comportamento atípico do comércio exterior do Brasil. Cano (2012) denuncia este erro de Peláez em relação à interpretação sobre os (supostos) efeitos da balança comercial sobre a recuperação econômica do pós-1930 como um erro primário do autor. 
Mudado o contexto externo, reduzida brutalmente a capacidade para importar, fechadas as fontes externas de crédito, impôs-se a saída na direção do mercado interno. [...]. A tudo isso correspondeu, nas esferas políticas, a ascensão de novos homens... Mas o fundamental não foi a ruptura dentro da classe dirigente, e sim a modificação fundamental no contexto externo. Foi essa mudança brutal e profunda do contexto externo que canalizou as energias do país em outra direção, desacreditou a ideologia do país "essencialmente agrário", fez com que os novos líderes vissem a realidade de outra forma. [...]. Mas não se imagine que os que chegaram ao poder em 1930 tinham percepção da natureza das mudanças que estavam em curso, ou que dispunham de um projeto para mudar o Brasil. Quando se tratava de formular política comercial, monetária ou fiscal, continuavam a predominar as idéias do passado. [...]. As mudanças foram impostas pelos fatos: as reservas de divisas se evaporaram e o crédito externo desapareceu; os impostos sobre importação, então os mais importantes, declinaram brutalmente; não havia possibilidade de atender ao serviço da dívida externa. [...]. O controle de câmbio não surgiu de uma escolha e sim da necessidade de sobreviver face à brutal baixa da entrada de divisas. Ninguém queimou café por masoquismo e sim para reduzir os imensos gastos de armazenamento e a pressão dos estoques sobre o mercado internacional. Ninguém dirá que José Maria Whitaker, o ministro da Fazenda da época, tinha idéias econômicas diferentes de Murtinho, como não demonstrara tê-las Getúlio Vargas quando ocupara a pasta da Fazenda no governo Washington Luís. [...]. Anos depois tive com Oswaldo Aranha uma conversa sobre esses acontecimentos e ele me observou: "Celso, você me explicou o sentido do que fizemos nessa época; então eu não sabia de nada”... Nada disso foi feito a partir de um projeto; foram antes atos de desespero. Ninguém pensou que isso pudesse ser uma forma de sustentar o mercado interno de produtos manufaturados; entretanto esse foi o resultado. (FURTADO, 1980, p. 713-717).

Nota-se pelo trecho acima que Furtado não apenas entendia as transformações da estrutura produtiva brasileira como impensadas pelos novos governantes, como enxergava nesse grupo um forte apego à ortodoxia econômica. ${ }^{11}$ No caso, a intencionalidade relacionar-se-ia puramente à necessidade de defender o setor cafeeiro, tendo sido o programa implementado pelo governo em razão da urgência imposta pelo cenário de crise externa que impactou adversamente o balanço de pagamentos e a arrecadação tributária.

A importância de se identificar a consciência decisória nas ações nos expoentes do Governo Provisório (1930-1933) e, posteriormente, tanto no Governo

11 Nesse depoimento de 1980, Furtado deixa mais explícita sua ideia de não intencionalidade industrializante da política econômica que ele já havia defendido em FEB. Estudos como, por exemplo, os de Abreu (1999), Fishlow (1972), Franco (1985) e Silber (1977) se dedicaram a discutir a política econômica dos anos 1930 e se ativeram especialmente a aspectos específicos da mesma, como as políticas fiscal, monetária e cambial. Por outro lado, estudos como os de Draibe (2004) e Fonseca (1986 e, especialmente, 2003), por exemplo, preferiam destacar mudanças institucionais e, no caso de Fonseca, atributos da formação intelectual e política de Vargas que se desdobrariam em novas formas de atuação do Estado na economia, dessa forma postulando em favor da existência de uma consciência decisória no primeiro governo Vargas em prol da industrialização. 
Constitucional de 1934-1937, quanto durante o Estado Novo (1937-1945), não se esconde por de trás de meras idiossincrasias ideológicas, mas se relaciona à possibilidade de se afirmar que os governantes conheciam ex ante, pelo menos em parte, os efeitos redistributivos de suas políticas, sendo possível, portanto, identificar novos compromissos firmados, pactos e condicionantes políticos nos cálculos do governo. Quando se parte das hipóteses da não intencionalidade e da colateralidade das alterações ocorridas na economia brasileira, acaba-se por assumir implicitamente o que defendeu Celso Furtado: que o aspecto "[...] fundamental não foi a ruptura dentro da classe dirigente". Mais do que isso, se as mudanças não partem da consciência decisória do governo, torna-se natural supor que os pactos que sustentaram politicamente o governo permaneceram inalterados, bem como "[...] as relações entre classes e frações de classes e entre Estado e economia". (BASTOS, 2008). A incompatibilidade da tese da não intencionalidade com os fatos históricos, diante da Revolução de 1930, tende a gerar dentro da obra de Furtado uma série de incoerências "[...] ao tentar explicitar a que segmentos sociais o governo mais se aproximava ou nele se faziam representar". (FONSECA, 2003, p. 139). Para ilustrar, podemos citar as palavras de Furtado (1964, p. 113), em que afirma que a Revolução de 1930 terminou "[...] afastando os grupos mais diretamente ligados à economia de exportação", para posteriormente defender que após a Revolução "[...] as classes que dirigem o país são, no essencial, as mesmas do período anterior".

Com o fito de tornar mais evidente a profunda alteração na orientação política e econômica do governo que se instalara após a crise de 1929, faz-se necessária uma breve digressão a respeito da inserção internacional do Brasil sob a tutela do padrão ouro-libra, bem como do modelo de superação de crises adotado pelos governos brasileiros até a ocasião da Grande Depressão, identificando as políticas macroeconômicas comumente utilizadas e as classes que se favoreciam e também as que saíam prejudicadas com os sucessivos ajustes externos - tarefa a ser empreendida na próxima subseção. Uma vez superada esta etapa, espera-se que a diferenciação entre as práticas políticas da República Velha e aquelas trazidas a cabo por Vargas se torne mais clara, para de imediato tornar mais fácil a identificação das classes cujos interesses passaram a ser deliberadamente contempladas nos discursos e práticas do novo governo que emerge em 1930. 


\subsection{Do Antigo ao Novo Modelo de Ajuste a Crises: o Embate Entre a Ortodoxia Importada e a Heterodoxia Prática}

Tal qual ressalta Bastos (2008, p. 189), o padrão ouro-libra constituiu um "[...] pilar central da criação de um sistema centro-periferia articulado em torno à economia britânica [...]”. É fundamental entender que esse regime monetário internacional dividiu o mundo entre países primário-exportadores e tomadores de empréstimos, de um lado, e países credores industrializados, de outro, tendo sido reservado à economia britânica o papel de emissora da moeda internacional.

Não obstante o padrão ouro-libra tendesse a aumentar o fluxo de comércio e de capitais internacional, ${ }^{12}$ sua sustentação em países periféricos, mesmo em momentos de expansão do fluxo de capitais e do comércio internacional, era potencialmente crítica e invariavelmente assimétrica. Isso porque a periferia se nutria de um enganoso e efêmero sentimento de equilíbrio externo curto-prazista nos ciclos de expansão mundial, dado tanto pelo próprio descasamento do balanço comercial, ${ }^{13}$ quanto também pelos efeitos dinâmicos, sobre as transações correntes, da contratação de novas dívidas via conta de capitais.

Ainda que países como o Brasil conseguissem conquistar superávits comerciais em alguns anos, o caráter estruturalmente deficitário nas contas de serviços e renda tendia a preservar tais países no ranking das nações tomadoras de empréstimos externos. Nesse sentido, cabe ressaltar a existência de uma inconsistência temporal no equilíbrio externo pautado em financiamentos sucessivos via conta capital de déficits estruturais nas transações correntes. Se, por um lado, a obtenção de capital externo em igual montante para cobrir o valor do déficit em transações correntes pudesse se mostrar suficiente para equilibrar o balanço de pagamentos em um dado período, por outro, a necessidade de pagamento dos serviços da dívida contraída tendia a aumentar o déficit na conta de serviços e rendas nos períodos subsequentes e, por conseguinte, a piorar a situação nas transações correntes. A contradição no caso é que o equilíbrio externo de curto prazo conquistado dessa forma tendia a rebater em desequilíbrios no longo prazo no balanço de pagamentos, aumentando a necessidade de contratação de crédito externo e amplificando a fragilidade financeira do país.

12 O fluxo de comércio e das finanças globais aumentaram puxados pelas facilidades que o padrão ouro-libra conferia às transações internacionais na medida em que este possibilitava a denominação do valor dos ativos e passivos em equivalentes monetários comuns (ouro e libra), posteriormente em função da estabilidade do valor dos ativos e da redução da incerteza em virtude do compromisso com taxas de câmbio fixas.

13 A raiz desse descasamento estava na sujeição da periferia em importar produtos com maior valor agregado do que aqueles que figuravam em sua pauta de exportações e, ainda, na maior elasticidade-renda das importações dos países subdesenvolvidos em relação aos países industriais, expressos nas transações comerciais entre centro e periferia. 
Dessa forma, dada sua condição de primário exportador, o Brasil durante um longo período foi condenado a se comprometer com as recomendações dos credores internacionais e com o ajuste amargo às crises conjunturais do padrão ouro-libra. O compromisso com os credores se pautava na condução ortodoxa da política macroeconômica, seja em tempos de expansão, visando à estabilidade das taxas de câmbio e, por conseguinte, dos valores esperados dos ativos e passivos expressos em moeda estrangeira, seja em tempos de crise, quando o ajuste recessivo (explicado mais abaixo) transmitia a mensagem de "bom comportamento" frente ao mercado financeiro global, supostamente habilitando ${ }^{14}$ aqueles que assim se portassem à participação de novas rodadas de (re)financiamento de débitos externos.

Não restam dúvidas que internamente um dos grandes problemas gerados pela operacionalidade do padrão ouro-libra (ou simplesmente pelo constante flerte com taxas de câmbio fixas) consistiu no constante constrangimento ao qual foram sujeitados a política monetária e o crédito doméstico. Isso porque, em um sistema de câmbio fixo, a base monetária se comporta de forma solidária com a entrada de reservas internacionais, em que pese o fato de inexistirem garantias de que essa entrada ocorreria no momento adequado e em quantidades condizentes com os desejos por novas inversões do empresariado nacional, conforme se depreende de Triffin (1964).

A baixa elasticidade do sistema creditício doméstico era aparente mesmo nos momentos de pujança da economia e das finanças globais. Entretanto, quando esse cenário se revertia - por vezes impulsionado por medidas restritivas nos países centrais, como a elevação da taxa de juros -, o ressentimento interno com a escassez de crédito era catalisado pela perda de reservas.

Embora a retração no crédito doméstico servisse automaticamente ao objetivo de (supostamente) reequilibrar as contas externas por meio da redução da absorção interna, o ajuste era quase sempre dramático e desproporcionalmente demorado. Isso porque as forças que empurravam a economia para o colapso das contas externas nos momentos de contração da economia global eram mais intensas e numerosas. De imediato, destaca-se que os fluxos de capitais afluíam para as praças financeiras mais seguras, em detrimento das mais rentáveis. Mais além, nos momentos de crise, os países industrializados possuíam débitos a receber, e não a pagar. Por fim, muitas dessas inflexões na trajetória de expansão do capitalismo global eram acompanhadas por uma piora nos termos de troca da periferia, dada uma redução mais acentuada nos preços das commodities vis-à-vis a redução do preço dos produtos industrializados (BASTOS 2008; FURTADO, 1959). Em suma, em um contexto em que se combinavam - e se combatiam com políticas ortodoxas - crises financeiras e crises no balanço de pagamento, a retração no produto,

14 Para uma interpretação crítica acerca do funcionamento do padrão-ouro, ver Triffin (1964). 
a deflação de ativos e a desvalorização cambial eram inevitáveis - especialmente nas nações com moeda inconversível (BASTOS, 2010a).

No Brasil, a desvalorização cambial no contexto de crise conjuntural global gerava um esforço hercúleo do governo para manter as contas públicas equilibradas ou superavitárias. Tendo em vista que a principal fonte de receita tributária do governo federal era o imposto sobre as importações, a retração no volume de comércio internacional, em virtude da crise, reduzia sensivelmente a arrecadação, enquanto a desvalorização cambial pressionava duplamente as contas públicas: pelo lado do gasto, com o encarecimento da dívida externa pública, e, pelo lado da receita, com o encarecimento das importações, o que tendia a reduzir o quantum importado.

O combate à crise externa deixava um gosto bastante amargo nos países (sobretudo os periféricos) que buscassem sua superação insistindo no receituário ortodoxo. O imperativo da valorização cambial, que atendia tanto aos desejos dos credores externos, quanto à necessidade de reduzir o peso da dívida pública contraída em moeda estrangeira, era perseguido pela condução contracionista nas políticas monetária e fiscal. No caso da política fiscal, o corte de gastos servia à necessidade (nem sempre exitosa) de equilibrar as contas externas via retração do produto, para o posterior pagamento do serviço da dívida. Já no caso da política monetária, a contração da base buscava deflacionar os ativos e bens com o fito de valorizar a moeda doméstica frente ao ouro e à libra. Resumidamente, ambas as políticas visavam à retração da demanda efetiva - tendo em vista seus efeitos sobre as importações - para tentar atingir o equilíbrio no balanço de pagamentos.

O evidente caráter pró-cíclico do ajuste econômico no padrão ouro-libra tornou o receituário de enfrentamento de crises um elemento amplificador da instabilidade social. A contração no valor dos ativos domésticos, a retração no nível da renda interna, além da baixa elasticidade do sistema creditício brasileiro - haja vista a ligação umbilical que este tinha com a entrada líquida de recursos externos -, colocavam barreiras quase intransponíveis ao empresariado nacional.

Para lidar com o dissabor dos ajustes, a República Velha precisou costurar novos pactos políticos capazes de sustentar a adoção das medidas de fidelidade à ortodoxia, necessárias à obtenção sucessiva de refinanciamentos externos. Surgia, assim, a Política dos Governadores, que conferia apoio dos parlamentares à adoção de medidas econômicas ortodoxas, em troca do apoio federal a questões estaduais (BASTOS, 2010a).

Essa forma de resolver as querelas republicanas acabou concentrando em demasia o poder político nas mãos das oligarquias paulista e mineira, inflamando o ressentimento regional e o descontentamento de outros setores da sociedade que clamavam por uma maior participação sobre os rumos da política econômica. Aos poucos, esse pacto político foi se desgastando, notadamente na década de 1920, 
conforme ficou expresso na intensificação da insurreição de conflitos federativos no período (FAUSTO, 1997; 2011).

A recorrência de crises políticas dos anos 1920 evidenciou dois fatores de extrema importância para o rumo da história política e econômica do país: a demanda crescente por apoio a outras culturas agrícolas, que viria a ser internalizada na plataforma do governo revolucionário através do discurso em favor do fomento à policultura; e o ressentimento também crescente com a monocultura cafeeira ante a impossibilidade dos demais estados ${ }^{15}$ de seguirem o mesmo rumo autônomo adotado por São Paulo. ${ }^{16}$ Ao final da década, este último fator, conjugado com a recusa de Washington Luís em utilizar déficits públicos e o crédito doméstico para socorrer algumas das oligarquias regionais em dificuldades financeiras (FAUSTO, 2006b), bem como a sua tentativa de impor Júlio Prestes à sucessão presidencial, esgarçaram por completo o tecido político da Primeira República. ${ }^{17}$

15 Dadas as características do mercado internacional do café em comparação com os respectivos mercados dos demais produtos brasileiros de exportação.

16 Na década de 1920, não era só o estado de São Paulo que requisitava a criação de um instituto federal de defesa do setor cafeeiro, mas outras oligarquias agrícolas também se fizeram ouvir e materializaram suas demandas em um projeto de lei para criação de institutos federais de defesa de seus produtos. A ideia era contar com recursos de emissões do Banco do Brasil, nos moldes do que havia sido feito na Primeira Guerra Mundial, quando os recursos externos se exauriram. Porém, em virtude da crise cambial e das finanças públicas - que dado o regime tributário brasileiro da época tendiam a ocorrer juntas - foi rejeitado o projeto de lei que tramitava no congresso para criação desses institutos. Em resposta à negativa do Congresso Nacional, São Paulo trouxe para si a responsabilidade de criar seu próprio instituto de defesa do café, lançando mão de seu poder político e econômico para alavancar recursos externos, utilizando-os inclusive para criação do Banco do Estado de São Paulo (Banespa).

17 Vale lembrar que uma das principais reivindicações dos grupos que compuseram o movimento revolucionário de 1930 era justamente que o voto se tornasse secreto, visando a moralização do processo eleitoral e o fortalecimento da democracia. A participação política na Primeira República era ínfima, não só porque uma parcela diminuta da população estava apta a votar, mas também pelo fato de que o voto não era obrigatório, segundo as leis eleitorais. Paradoxalmente, porém, havia uma vida política relativamente ativa no país, especialmente nas regiões urbanas. Vale citar uma passagem de Mattos (2011, p. 100): "Apesar da baixa participação eleitoral da capital nas eleições de 1894 (num eleitorado potencial de 110 mil pessoas, votaram 7.857 eleitores), a politização nas ruas do Rio em torno de uma agenda social ligada aos interesses das camadas populares, difusamente de inspiração positivista, foi parte integrante do contexto da primeira década republicana." À medida que avançava a urbanização, esse pleitos, difusamente ou não, também se materializavam. Basta lembrar, por exemplo, que, na campanha pela presidência em 1919, Rui Barbosa propôs ativamente a adoção de uma legislação operária (MATTOS, 2011). Nos anos 20, avolumam-se as revoltas civis e também de militares, de tal forma que a Revolta do Forte de Copacabana (5 de julho de 1922) e, principalmente, a Coluna Prestes (iniciada em 1924 e que durou três anos) foram eventos precursores de movimentos que depois se reuniriam em torno do que se chamaria de Tenentismo, com diversos integrantes militares dos mesmos tendo tido participação ativa no suporte da Revolução de 1930. Embora seja simplificador descrever apenas por números as características do processo eleitoral e funcionamento da política da Primeira República, não é demais sublinhar, por exemplo, que na eleição de 1906, que levaria Afonso Pena à Presidência da República, apenas o equivalente a 1,4\% da população total votou, percentual que subiu para apenas 5,7\% da população total quando foi eleito Júlio Prestes, em 1930. 
Na seguinte passagem, Bastos (2001) resume bem as circunstâncias que animaram aquele momento histórico, destacando como a própria particularidade da formação política de seus líderes influenciou pesadamente os rumos da revolução:

Seja como forem suas convicções doutrinárias, entretanto, Vargas, Whitaker e Aranha não eram professores ou teóricos, eram políticos envolvidos com a gestão de políticas econômicas em um contexto restritivo. Sendo assim, mais do que enfatizar as restrições ideológicas e doutrinárias que herdaram de seu passado como políticos da República Velha, é preciso identificar tanto aquilo que os obrigava a não implementarem sempre as políticas ortodoxas que viam ainda como desejáveis em circunstâncias ideais, como aquilo que os disciplinava, se não o suficiente para que conseguissem implementar políticas ortodoxas em um cenário em que elas seriam desastrosas, pelo menos para manter as aparências. (BASTOS, 2001, p. 170).

Nesse sentido, não parece correto afirmar que a Revolução de 1930 tenha surgido como um programa heterodoxo no instante de sua consagração. É sabido pelos discursos e pela vida política de Vargas que suas convicções estavam, em certa medida - em função de sua proximidade e simpatia com a ideologia positivista -, próximas da ortodoxia. O que se deve sublinhar, entretanto, é que os aspectos da heterodoxia de Vargas, enquanto presidente, acabariam se sobressaindo sobre os aspectos ortodoxos de seu pensamento ${ }^{18}$ diante da realidade expressa pela crise. No plano nacional cresciam as demandas de diversos setores, agrários e industriais, ligados à necessidade de sustentação da renda interna e de expansão creditícia. Ciente dos reclames, Vargas discursou em respeito à urgência de se reformar o Banco do Brasil com a finalidade de torná-lo

[...] um propulsor do desenvolvimento geral, auxiliando, nesse caráter, a agricultura, amparando o comércio, fazendo redescontos, liderando, em suma, todo o sistema bancário, no sentido do contínuo engrandecimento do país. Atingir-se-á esse objetivo mediante a criação de carteiras especiais para o comércio, para a agricultura, para as indústrias etc. Além do café, outros produtos estão a reclamar produção e defesa. Entendo que o problema só terá solução quando for criada no Banco do Brasil uma carteira agrícola. Esta deverá atender às necessidades do produtor, isto é, facilitar-lhe os recursos necessários tanto para o desenvolvimento da produção quanto para o aperfeiçoamento da produção [...] O que aí se preconiza em relação ao açúcar, tem aplicação plena quanto ao algodão, aos cereais em geral, a erva-mate, ao cacau etc. É o que se tem feito, no meu Estado, com o charque, com o arroz, a banha e o vinho [...]. No Rio Grande, o governo intervém junto aos produtores, apenas, com o adiantamento do numerário, garantido pela produção, e com a fiscalização [...]. (VARGAS, 1930, p. 55 apud BASTOS, 2008, p. 17).

18 Para mais informações sobre a formação intelectual e o pragmatismo de Vargas, ver Bastos (2010b) e Fonseca (1989), cap. 2. 
É notável, nesse contexto, que a crise que se instalou em 1929 e que assolou a economia global durante a década seguinte não representava uma simples crise conjuntural. Ruía, com a crise, o padrão-ouro - símbolo do então já vetusto regime monetário internacional. O comércio se contraía em ritmo acelerado, fechando os países em pequenos blocos. Enxugava-se a liquidez externa. Na medida em que tais transformações avançavam, os credores externos perdiam a capacidade de impor condições aos países endividados, e passavam a se contentar com a já reduzida capacidade de sugerir medidas ao conjunto desses países. ${ }^{19}$ Desacreditava-se o liberalismo ao redor do mundo, na sua dimensão política e econômica. ${ }^{20} \mathrm{~A}$ ausência de teorias que pudessem fornecer respostas diferentes, apropriadas ao cenário de profunda desestruturação da ordem econômica global, conduziu os países, endividados ou não, a uma rica fase de experimentação, da qual o próprio governo provisório brasileiro, em face da nova coalizão política interna e do pragmatismo e da formação intelectual de Vargas, se utilizou.

\subsection{Evidências de uma Reorientação Produtiva Heterodoxa e Consciente}

A reorientação produtiva pela qual passou a economia brasileira na década que se segue à crise de 1929 deve ser entendida como reflexo tanto do novo arco de alianças políticas que sustentaram a Revolução de 1930, quanto da desestruturação da economia global. Conforme demonstra Furtado em sua análise seminal, tais fatos criaram as condições para que a política econômica lançada no pós-crise de 1929, como resposta às restrições externas e à nova configuração política interna, acabasse moldando as transformações produtivas que caracterizariam a economia brasileira nos anos 30.

Enquanto o primeiro fenômeno evidenciava a necessidade de atender novas demandas em função dos novos pactos políticos de sustentação do poder, o segundo relaxava as restrições externas - no plano político/ideológico, mas não no econômico -, dado o enfraquecimento do poder disciplinador dos credores internacionais (e o descrédito do liberalismo). É bem verdade que, associado ao conjunto dessas mudanças, havia sim um comportamento reativo de Vargas e sua equipe econômica, principalmente ao perceber a crise global como uma janela de oportunidade para a condução da política econômica de forma anticíclica e que seria executada, conforme postulamos neste artigo, de forma intencional.

Na condução da política monetária, o primeiro indício de consciência decisória é dado pelo discurso de Vargas citado anteriormente em defesa da reforma

19 Lembrar que a própria Inglaterra viu-se obrigada a anunciar o abandono do padrão-ouro em setembro de 1931.

20 Alguns exemplos mais conhecidos de rompimento com o liberalismo são o New Deal norte-americano e a política econômica implementada pelo regime nazista - embora ambos, evidentemente, atendendo a princípios e ideologias bastante diferentes. 
do Banco do Brasil e em favor do uso do crédito público doméstico para fomentar diversas atividades agrícolas e industriais. Destaca-se, ainda, a criação da Carteira de Crédito Agrícola e Industrial do Banco do Brasil no ano de 1937. Esses dois fatos evidenciam tanto o caráter anticíclico na condução da política monetária e creditícia, quanto o compromisso assumido por Vargas com outros setores produtivos da sociedade que não os representados pela oligarquia paulista. Além disso, expressam a intencionalidade (não só em forma de discurso, mas de atos concretos) dos governantes em promover a industrialização no país.

Em termos numéricos, segundo sugerem os dados referentes aos agregados monetários, a política monetária do país entrou em uma trajetória claramente expansionista, tendo o papel-moeda emitido e os meios de pagamento crescido de forma célere entre os anos de 1930 e 1939, com exceção para os anos de 1930 e 1933.

Em relação à forte contração no ano de 1930, três considerações merecem ser feitas. Primeiro, destaca-se o efeito contracionista sobre a base monetária da evaporação das reservas internacionais pela operação da Caixa de Estabilização (NEUHAUS, 1975). Além disso, não parece correto atribuir tal retração a Vargas, visto que este assume o poder somente em novembro de $1930 .{ }^{21}$ Por fim, dada a forte deflação observada, as contrações reais no papel-moeda emitido e nos meios de pagamento foram menores do que supõem as alterações nominais nessas variáveis.

Em relação ao ano de 1933, para obter recursos não orçamentários, o "Tesouro sacou sobre os depósitos do Banco do Brasil correspondentes aos atrasados comerciais não transferidos e aos pagamentos não efetuados relativos à dívida externa", não tendo sido necessário, portanto, a utilização intensiva das emissões monetárias (FRANCO, 1985, p. 413). Por fim, Franco (1985) ainda destaca o uso das "[...] emissões encobertas sob a forma de transferências bancárias fora do orçamento [...]" direcionadas ao desconto de letras do Conselho Nacional do Café. Sobre esse aspecto, chama a atenção o fato dos empréstimos do Banco do Brasil para o governo (federal, estadual e municipal) e suas entidades e autarquias (incluindo o Departamento Nacional do Café) terem saltado de 1.329 .000 contos de réis, em 1932, para 2.731.000 contos de réis em 1939, segundo Neuhaus (1975).

Tendo sido expostas as considerações acerca das retrações do papel-moeda emitido (PME) para os anos de 1930 e 1933, convém explicar também os anos em que a emissão de papel-moeda se expandiu em ritmo mais lento do que a variação no nível de preços, sendo eles: 1934, 1936 e 1938. A variação real negativa no papel-moeda emitido poderia sugerir que a condução da política monetária

21 Há de ser lembrado que uma das primeiras medidas do governo provisório foi o pronto fechamento da caixa de estabilização (Decreto ${ }^{\circ} 19.423$, de 22 de novembro de 1930), que, ao permitir a desvalorização do mil-réis, devolveu graus de liberdade à política monetária, permitindo a prática deliberada de expansão do papel moeda emitido durante toda a década. 
nesses anos seguiu um caráter ortodoxo. Entretanto, no ano de 1934, se por um lado não houve variação real positiva em PME, por outro, o governo implementou uma forte redução dos caixas das autoridades monetárias, reduzindo o entesouramento no setor bancário da economia e transferindo recursos para o setor não bancário, de modo que o efeito final sobre os meios de pagamentos foi positivo em termos reais, conforme mostra a Tabela 1 . O mesmo tipo de política foi praticado em 1936. Contudo, em virtude da alta taxa de inflação verificada naquele ano, não é possível afirmar que a política monetária seguiu uma trajetória de expansão real, muito embora o papel-moeda emitido e os meios de pagamento tenham se expandido em 12,13\% e 11,33\%, respectivamente. Ante as taxas de expansão nominal apresentadas por essas variáveis, torna-se no mínimo problemática a aceitação de que a política monetária tenha seguido orientações que não aquelas voltadas à superação da crise, à consolidação dos novos pactos políticos e ao fomento da reorientação da estrutura produtiva brasileira, todas referendadas pela expansão da oferta de moeda. ${ }^{22}$

Tabela 1 - Taxa de crescimento dos agregados monetários, inflação e multiplicador monetário

\begin{tabular}{lcccccccc}
\hline Ano & $\begin{array}{c}\text { Papel Moeda } \\
\text { Emitido }\end{array}$ & $\begin{array}{c}\text { Papel } \\
\text { Moeda em } \\
\text { Poder do } \\
\text { Público }\end{array}$ & $\begin{array}{c}\text { Caixa nas } \\
\text { Autoridades } \\
\text { Monetárias }\end{array}$ & $\begin{array}{c}\text { Caixa nos } \\
\text { Bancos } \\
\text { Comerciais }\end{array}$ & $\begin{array}{c}\text { Depósitos à } \\
\text { Vista }\end{array}$ & $\begin{array}{c}\text { Meios de } \\
\text { Pagamento } \\
\text { (M1) }\end{array}$ & Inflação & $\begin{array}{c}\text { Multiplicador } \\
\text { Monetário }\end{array}$ \\
\hline $\mathbf{1 9 3 0}$ & $-16,20 \%$ & $-8,33 \%$ & $-53,19 \%$ & $-1,04 \%$ & $-18,61 \%$ & $-14,69 \%$ & $-8,99 \%$ & 1,75 \\
$\mathbf{1 9 3 1}$ & $3,51 \%$ & $3,64 \%$ & $-13,62 \%$ & $12,74 \%$ & $24,68 \%$ & $16,06 \%$ & $-3,70 \%$ & 1,94 \\
$\mathbf{1 9 3 2}$ & $9,95 \%$ & $9,36 \%$ & $64,16 \%$ & $-11,61 \%$ & $21,97 \%$ & $17,35 \%$ & $0,43 \%$ & 2,13 \\
$\mathbf{1 9 3 3}$ & $-6,21 \%$ & $0,27 \%$ & $-17,25 \%$ & $-22,42 \%$ & $-1,85 \%$ & $-1,13 \%$ & $-0,85 \%$ & 2,19 \\
$\mathbf{1 9 3 4}$ & $3,95 \%$ & $7,54 \%$ & $-17,68 \%$ & $4,51 \%$ & $15,70 \%$ & $12,88 \%$ & $7,73 \%$ & 2,37 \\
$\mathbf{1 9 3 5}$ & $14,41 \%$ & $19,73 \%$ & $-11,22 \%$ & $4,32 \%$ & $-1,88 \%$ & $5,24 \%$ & $5,58 \%$ & 2,17 \\
$\mathbf{1 9 3 6}$ & $12,13 \%$ & $15,32 \%$ & $-23,83 \%$ & $13,87 \%$ & $8,93 \%$ & $11,33 \%$ & $14,72 \%$ & 2,14 \\
$\mathbf{1 9 3 7}$ & $12,35 \%$ & $5,99 \%$ & $89,10 \%$ & $20,91 \%$ & $14,30 \%$ & $11,07 \%$ & $4,61 \%$ & 2,14 \\
$\mathbf{1 9 3 8}$ & $6,04 \%$ & $2,67 \%$ & $38,85 \%$ & $4,06 \%$ & $32,55 \%$ & $21,48 \%$ & $7,23 \%$ & 2,48 \\
$\mathbf{1 9 3 9}$ & $3,03 \%$ & $7,68 \%$ & $-34,66 \%$ & $9,10 \%$ & $-9,64 \%$ & $-4,22 \%$ & $2,64 \%$ & 2,31 \\
\hline
\end{tabular}

Fonte: Elaboração própria a partir de dados fornecidos por Ipeadata (2015) e IBGE (1941).

22 A simples constatação de que a política monetária seguiu uma trajetória expansionista na década de 1930 pouco revela sobre o caráter intencional e heterodoxo das medidas implementadas no período, sobretudo se se tem ciência de que as décadas anteriores também apresentaram surtos de emissão monetária (embora geralmente relacionados à entrada de reservas internacionais). Nesse sentido, a força do argumento em favor da intencionalidade reside no conjunto de medidas das políticas instrumentais, as de criação de órgãos para ampliar a ação estatal, ao lado de fatores de ordem política. Todas essas medidas e decisões, tomadas conjuntamente, atuaram no intuito de deslocar o padrão de acumulação, antes voltado para fora (exportações), para o mercado interno, conforme se pretende mostrar mais à frente, reforçando argumentos já expostos até este momento. 
Em relação ao ano de 1938, mais uma vez diante de uma elevada taxa de expansão do PME (na ordem de 6,04\%), a política monetária teve um caráter contracionista em termos reais. Somado a esse fato, o governo não estimulou ou tampouco se utilizou de forma compensatória do caixa nas autoridades monetárias como intermédio para impactar positivamente os meios de pagamento da economia, tal qual fizera nos anos anteriores. Ao contrário, praticou uma forte expansão dos recursos contidos em caixa, de modo que o impacto positivo sobre o M1 deve ser explicado pela elevação considerável nos depósitos à vista. Há de ser dito que essa constatação não sustenta a hipótese de que a política macroeconômica foi conduzida de forma ortodoxa, pois o que ocorre no ano de 1938 é simplesmente uma alteração substancial na fonte de financiamento dos déficits públicos, reduzindo o recurso a emissões monetárias, de um lado, e elevando a emissão de títulos, de outro. A Tabela 2 parece ratificar essa hipótese, uma vez que é justamente no ano de 1938 que a emissão de títulos atinge seu valor mais expressivo no período em questão.

Tabela 2 - Variação de caixa do Tesouro (em mil contos de réis)

\begin{tabular}{|c|c|c|c|c|c|c|c|c|c|c|c|}
\hline & 1928 & 1929 & 1930 & 1931 & 1932 & 1933 & 1934 & 1935 & 1936 & 1937 & 1938 \\
\hline \multicolumn{12}{|l|}{ Resultado Operacional } \\
\hline Receita & 2215 & 2399 & 1677 & 1753 & 1695 & 2604 & 1971 & 2723 & 3127 & 3462 & 3880 \\
\hline Despesa & 2028 & 2224 & 2465 & 2176 & 2875 & 3343 & 2099 & 2872 & 3226 & 4143 & 4785 \\
\hline Outros & -51 & -188 & -326 & -5 & -357 & -162 & -42 & -42 & -20 & 90 & -234 \\
\hline Transferências a Bancos & - & - & - & - & - & - & 161 & -464 & 362 & -573 & -272 \\
\hline Resultado & 137 & -12 & -1114 & -428 & -1537 & -901 & -9 & -655 & -481 & -1164 & -1355 \\
\hline \multicolumn{12}{|l|}{ Financiamento } \\
\hline Variação na Caixa & 583 & 89 & 257 & 43 & 334 & -28 & 8 & 25 & -2 & - & -3 \\
\hline Títulos & -720 & -40 & 263 & 167 & 436 & -18 & -63 & 172 & 25 & 459 & 1016 \\
\hline Papel-Moeda & - & - & 592 & - & 398 & -64 & - & -45 & 268 & 662 & 348 \\
\hline Depósitos da Dívida Extema & - & - & - & - & 370 & 1011 & -36 & - & - & - & - \\
\hline Outros & - & - & - & 219 & - & - & 100 & 500 & 109 & 43 & - \\
\hline Resultado Segundo o Anuário & -133 & -221 & -832 & -294 & -1109 & -313 & -530 & -149 & -98 & -681 & -855 \\
\hline
\end{tabular}

Fonte: Franco (1985).

Outro indício relevante da condução anticíclica da política macroeconômica na década de 1930 se apoia na elevação da oferta de moeda (M1), fenômeno capturado pelo aumento do multiplicador bancário da economia brasileira no período (ver Tabela 1). Em 1930, o valor do multiplicador era inferior a 1,75, de modo que variações unitárias na base monetária geravam menos de 1,75 unidade nos meios de pagamento. Em 1934, o valor atinge a expressiva marca de 2,37, atingindo o seu pico em 1938 com o valor de 2,48, para posteriormente recuar ao valor de 2,31 (ver Tabela 1). Chama a atenção o fato de que durante o Governo Provisório - fase em que se concentrou a crise internacional - o valor do multiplicador se elevou em cerca de 36\%, estando, portanto, de acordo com a visão de Vargas em relação à expansão do crédito interno como meio para superar os efeitos negati- 
vos da crise sobre o nível de renda da economia, como também para reposicionar a estrutura produtiva do país na direção da industrialização.

A rigor, o crescimento do multiplicador reflete sobremaneira a queda na razão encaixes/depósitos à vista dos bancos. A razão, que era de aproximadamente 0,368, em 1929, caiu para 0,319, em 1930, e atingiu, em 1939, o valor de 0,157. Essa redução substancial do entesouramento do setor bancário traduz uma série de reformas sofridas nesse segmento, em sua maioria lideradas pelo Banco do Brasil e solidárias com a necessidade de superação da crise econômica. Destaca-se, nesse processo, a criação da Carteira de Redesconto do Banco do Brasil (CRBB) (Decreto $n^{\circ} 19.525$ de 24 de dezembro de 1930), que reestabeleceu sua condição de emprestador de última instância, possibilitando que as demais instituições do setor bancário reduzissem suas margens de segurança (percentual de encaixes). É igualmente digna de nota a criação, em 1932, da Carteira de Mobilização Bancária (Camob), cuja função principal era absorver parte dos ativos ilíquidos que estavam atravancando as carteiras dos bancos. Ao prover recursos líquidos às instituições bancárias, a Camob favoreceu a elevação dos empréstimos bancários como proporção dos depósitos. Neuhaus (1975) ainda acentua que a Camob e a Carteira de Redesconto foram imprescindíveis para financiar as necessidades do Tesouro e do Departamento Nacional do Café, sendo a carteira também importante para redescontar títulos de origem agrícola, industrial e, posteriormente, do próprio Tesouro.

Já no tocante à política fiscal, o período de práticas expansionistas deliberadas parece só ter surgido a partir do ano de 1933. De fato, após esse ano os déficits passaram a ser planejados, e não mais frutos de subestimação de receitas orçamentárias, como fica evidente na Tabela 3. Se, por um lado, a prática de déficits durante todo o período evidencia o caráter anticíclico da política fiscal, os déficits planejados após o ano de 1933 parecem apontar para a consciência da equipe do governo de que, dada a situação da economia global, era mais oportuno atender as demandas dos setores industriais e agrícolas pela sustentação da renda interna do que se comprometer com os ajustes pró-cíclicos ortodoxos que atendiam às recomendações dos credores externos. ${ }^{23} \mathrm{Ou}$ seja, a necessidade de legitimação política de um governo que acabara de ascender ao poder se materializou sob a forma de incorporação do discurso da defesa da policultura e da indústria nacional, pressionando (a contragosto dos credores) a necessidade de gastos para níveis mais elevados. ${ }^{24}$ Ainda em relação aos déficits públicos praticados na década de

23 O dado de 1932 é atípico, em virtude das necessidades de incorrer em gastos extraordinários, tanto para enfrentar a revolta paulista, quanto para socorrer a especialmente severa seca nordestina desse ano.

24 Deve-se ressaltar, porém, que, ao optar pela sustentação da renda interna, Vargas não rompia com o setor cafeeiro, pois a única possibilidade a curto prazo de sustentação do nível doméstico de atividades se dava justamente através da defesa da renda desse setor. Tal qual revela Vargas em seu discurso em 1931: "Economicamente, o país caíra em verdadeiro colapso. A retenção prolongada do café nos reguladores paulistas obstruía literalmente os mercados nacionais, impedindo os 
1930, Franco (1985) fornece uma metodologia distinta de cálculo, considerando outras formas de receita e despesa. Ao assim fazê-lo, o autor chega a resultados para o déficit público geralmente bem superiores (ver Tabela 3) do que aqueles apresentados pelo Anuário Estatístico 1939/40 do IBGE. Entre os anos de 1930 a 1933, tal metodologia constatou déficits em média 56\% maiores quando comparados ao Anuário, enquanto entre 1935 e 1938 os déficits observados foram cerca de 83\% maiores se comparados ao mesmo documento (ver Tabela 2).

Tabela 3 - Execução orçamentária do governo federal

\begin{tabular}{c|ccc|ccc}
\hline \multirow{2}{*}{ Ano } & \multicolumn{3}{|c|}{ Orçamento } & \multicolumn{3}{c}{ Execução Orçamentária } \\
& Receita & Despesa & Saldo & Receita & Despesa & Saldo \\
\hline 1930 & 2365 & 3020 & -655 & 1674 & 2510 & -836 \\
1931 & 2670 & 2452 & 218 & 1752 & 2046 & -294 \\
1932 & 2242 & 2217 & 25 & 1695 & 2859 & -1164 \\
1933 & 2125 & 2101 & 24 & 2096 & 3292 & -296 \\
1934 & 2086 & 2355 & -269 & 2518 & 3050 & -532 \\
1935 & 2169 & 2691 & -522 & 2723 & 2872 & -149 \\
1936 & 2537 & 2893 & -356 & 3127 & 3226 & -99 \\
1937 & 3218 & 3726 & -508 & 3462 & 4143 & -681 \\
1938 & 3824 & 3875 & -51 & 3880 & 4735 & -855 \\
1939 & 4070 & 4065 & -5 & 4297 & 4850 & -533 \\
\hline
\end{tabular}

Fonte: Villela e Suzigan (1973).

Diante do exposto, torna-se evidente a diferença entre o ritmo de abandono da ortodoxia na política fiscal e na monetária. Vargas parece ter percebido muito antes a necessidade de expansão do crédito como política anticíclica. Nesse sentido, a própria experiência exitosa de Getúlio com a criação do Banco do Estado do Rio Grande do Sul (BERGS) (ocorrida em 1928, quando ele era governador do estado do Rio Grande do Sul) forneceu-lhe um rico roteiro de ações a ser seguido. ${ }^{25}$ No que concerne à política fiscal, o rompimento deliberado com a ortodoxia só parece ter ocorrido após 1933, tendo sido igualmente fruto da experimentação prática. Nesse sentido, a aversão de Getúlio à inflação parece arrefecer com a necessidade de sustentar a renda interna e com a constatação de que os déficits

lavradores de vender, ou sequer, de caucionar o que produziam. Em consequência, cessaram eles os seus pagamentos aos próprios colonos, e, por tal motivo, os comerciantes do interior, privados de receber o que já tinham adiantado, colocaram os atacadistas em dificuldades extremas, que se refletiam, por seu turno, nas indústrias, paralisando o respectivo movimento [...]. A urgência de restabelecer o ritmo de nossa vida econômica determinou a providência da compra dos stocks [...]”. (VARGAS, 1931 apud CORSI, 2000, p. 38-39).

Para mais informações, ver Bastos (2008). 
observados desde o início de seu governo, notadamente aquele constatado para o ano de 1932, não geravam pressões inflacionárias nos níveis que se supunha (pelo contrário, a economia vivia períodos de deflação, diante do cenário grave deflagrado pela crise).

Não foram apenas a adoção de políticas monetárias, creditícias e fiscais expansionistas que forneceram evidências de que a necessidade de costurar novos pactos de sustentação de poder se sobrepuseram às antigas recomendações ortodoxas dos credores internacionais. Tampouco, a consciência decisória acerca das transformações estruturais da economia brasileira se sustenta somente na identificação de déficits públicos planejados a ser financiados, entre outras fontes, via emissão monetária. ${ }^{26} \mathrm{Na}$ realidade, a partir da década de 1930, diversos órgãos foram criados, modificando a relação entre Estado e economia e, sobretudo, alterando a relação das classes cujos interesses encontravam-se contemplados nas ações do novo governo.

Sob uma perspectiva institucionalista, a constatação da criação desses novos órgãos fornece um rico argumento em favor da intencionalidade do governo no sentido de promover alterações econômicas (principalmente na reorientação produtiva), sociais e políticas. No plano da economia, destacam-se, além dos órgãos já mencionados (CRBB e Camob), a criação da Carteira de Crédito Agrícola e Industrial do Banco do Brasil, o Conselho Técnico de Economia e Finanças, ambos de 1937, a Companhia Siderúrgica Nacional, na primeira metade da década de 1940 e, ainda, a criação de institutos federais orientados para a defesa de diversos produtos agrícolas (DRAIBE, 1985; FONSECA, 2003). No plano social e político, a criação de leis trabalhistas e a construção de um sistema de bem-estar embrionário e corporativo podem ser enxergadas como medidas que dão indícios de uma maior responsabilização do Estado brasileiro no processo de avanço industrial (FONSECA, 2003; KERSTENESTKY, 2012).

Ademais, ainda no plano institucional (no sentido aqui adotado), cabe sublinhar as medidas tomadas no âmbito da regulação cambial, ${ }^{27}$ que podemos resumir citando os seguintes decretos, conforme apontam Van der Laan, Cunha e Fonseca (2012): a) Decreto $n^{\circ} 20.451$, de 1931, que estabelece o regime de monopólio cambial, tornando o Banco do Brasil o órgão responsável pela compra de moeda

26 A seguinte passagem de Fonseca (2003) é esclarecedora: “[...] nem sempre estas políticas instrumentais são capazes de evidenciar intencionalidade, dificultando que de sua formulação ou execução se possam depreender claramente as intenções de seus formuladores, o mesmo não ocorre com as instituições criadas, extintas ou alteradas. O exame destas pode mostrar-se valioso metodologicamente ao permitir, com maior facilidade e precisão, que sejam empiricamente reveladas intenções, planos e projetos, porquanto em geral resultam de atos deliberados, que precisam ser expressos não só 'fisicamente' (caso de órgãos, institutos, ministérios, associações), como pela escrita (caso de leis, códigos e alguns símbolos) ou pela linguagem oral (caso de discursos e entrevistas, por exemplo)" (FONSECA, 2003, p. 134).

27 E ainda ficando em medidas relacionadas às "políticas instrumentais", segundo Fonseca (2003). 
estrangeira para todas as transações envolvendo o mercado externo (ou seja, não apenas as exportações, mas principalmente estas, pois eram as transações mais volumosas); b) Decreto $\mathrm{n}^{\circ} 23.258$, de 1933, que garante a obrigatoriedade de cobertura cambial, exigindo, por exemplo, que os exportadores internalizassem as receitas em moeda estrangeira (vendendo-as obrigatoriamente ao Banco do Brasil, conforme o Decreto $n^{\circ} 20.451$, de 1931); c) Decreto $n^{\circ} 23.501$, editado em novembro de 1933, e que institui o "curso forçado" do papel-moeda, o que significa, na prática, a institucionalização do abandono do padrão-ouro.

Dessa forma, através dos dois primeiros decretos, o governo federal garantia não apenas o controle sobre todos os fluxos de moeda estrangeira, como também permitia discriminar o seu uso, priorizando, no caso, "[...] a destinação das cambiais para a importação de mercadorias direcionadas à industrialização interna" (VAN DER LAAN; CUNHA; FONSECA, 2012, p. 602). Além disso, viabiliza-se o reforço de medidas de desvalorização cambial e também o estabelecimento de cotas e licenças de importação. Esses instrumentos, portanto, certamente favoreceram o processo de substituição de importações e também revelaram claras intenções industrializantes.

No caso do terceiro decreto mencionado, fica claro que tornava possível a posterior execução de uma política monetária expansiva, pois, a partir de então, sem as amaras do finado padrão-ouro, a moeda tornava-se fiduciária e inconversível. ${ }^{28}$

Portanto, pode-se concluir que a mudança da política cambial surgia como uma resposta - apoiada pela coalização política que emerge ao poder com Vargas em 1930 - aos problemas do balanço de pagamentos, mas não apenas a isso. A mudança na política cambial não se limitou, portanto, à adoção de uma moeda mais desvalorizada. Ela apresentou um conteúdo de significativas (e o tempo mostraria, duradouras) mudanças estruturais, tendo sido importante para as décadas seguintes, caracterizadas como o período de ocorrência do processo de substituição de importações (TAVARES, 1972).

\section{Considerações Finais}

Embora Furtado (1959) tenha acertado ao sublinhar a importância dos gastos com o programa de defesa do café para a rápida recuperação do nível de atividade da economia brasileira, e, ainda, ao atentar para a relevância desses gastos (em conjunto com a desvalorização cambial) para promover a industriali-

28 A intenção industrializante (pois estimula importações de equipamentos para aparelhar a indústria) também se revela no comentário dos autores, que destacam que, por este decreto, vedava-se "[...] a estipulação de pagamento em ouro ou moeda estrangeira para transações entre residentes, o que reduzia legalmente a pressão de demanda por escassa moeda conversível (priorizada) para importação" (VAN DER LAAN; CUNHA; FONSECA, 2013, p. 604). 
zação, deslocando o centro dinâmico da economia nacional na direção do mercado interno, parece ter se equivocado ao caracterizar tais resultados como não intencionais, como também ao desconsiderar os impostos como uma das fontes financiadoras da política fiscal na época, tal qual supôs Peláez (1971).

Em relação à importância da mudança no contexto externo para a superação da crise, é incontestável que a desestruturação da economia global depositou sobre os governos nacionais uma boa dose de autonomia decisória, principalmente após o abandono, pela Inglaterra, do padrão ouro-libra, em 1931. O cataclismo da economia e das finanças globais enfraqueceu o poder mandatório dos centros financeiros internacionais sobre os rumos políticos e econômicos da periferia endividada. Isso tudo, na prática (e não apenas no Brasil), significou o progressivo questionamento político e ideológico à ortodoxia e ao liberalismo, conforme lembrou Bastos (2010a). No Brasil, a restrição externa, em sua dimensão econômica, se elevava na forma de uma crise siamesa no balanço de pagamentos e nas finanças públicas e, em sua dimensão política, acirrava ressentimentos regionais e gerava instabilidade social.

No cenário interno, a Revolução de 1930 deixou clara a reorientação de forças políticas dentro do poder. O abandono da monocultura em favor da policultura e da indústria surge como fruto de novos pactos políticos sustentados pelo novo governo em troca de sua legitimidade e representatividade. Essas mudanças já vinham sendo gestadas desde pelo menos os anos 1920, marcados por significativas mudanças na estrutura produtiva e, não por mera coincidência, por um crescente número de crises e sublevações políticas em todo o território nacional.

Se, por um lado, dado um contexto externo economicamente adverso, os credores internacionais apontavam para a necessidade do governo brasileiro cortar gastos, por outro, internamente, a descontinuidade do processo político, representado pela Revolução de 1930, ao estabelecer novos pactos políticos a serem atendidos, apontava em sentido oposto. No cabo de guerra entre essas duas forças, a segunda acabou prevalecendo, de modo que durante toda a década de 1930 foi possível observar a ocorrência de déficits fiscais. ${ }^{29}$ Nesse sentido, chamam a atenção os déficits planejados a partir de 1934, que sugerem o rompimento prático definitivo dos representantes do governo com as concepções ortodoxas.

De forma não menos importante, cabe ressaltar o papel operativo da política monetária e creditícia na recuperação da economia brasileira, enquanto fonte de financiamento para as necessidades crescentes dos gastos públicos. Não apenas o recurso de emissão foi utilizado, mas também subtração do caixa nas autoridades

29 Vale destacar que, ao mesmo tempo, a economia brasileira pós-1930 não foi marcada por um descontrole da inflação depois que a recuperação produtiva havia se materializado. Além disso - e mais importante -, o crescimento do PIB per capita dos anos 30 foram bastante superiores ao que havia caracterizado o período da Primeira República, conforme bem reconheceram Franco e Lago (2012). 
monetárias, saques do Tesouro sobre depósitos do Banco do Brasil destinados ao pagamento de atrasados comerciais, além de emissões encobertas sob a forma de transferências bancárias. Chama a atenção, ainda, a consistente elevação do valor do multiplicador bancário durante a década de 1930, calculado com base em dados disponíveis dos agregados monetários. Este fato - a elevação do multiplicador bancário, conforme demonstrado neste artigo - referenda a hipótese de expansão do crédito doméstico no período. O raio de manobra dessas políticas foi viabilizado, de resto, pelo conjunto de medidas de regulações cambiais tomadas ainda no Governo Provisório, conforme se depreende do estudo de Van der Laan, Cunha e Fonseca (2012).

Em suma, diante do exposto, torna-se insustentável a aceitação do argumento segundo o qual o processo de reorientação produtiva ocorrido a partir de 1930 deveria ser entendido simplesmente como um subproduto não intencional da política de sustentação da renda cafeeira, tal qual argumenta Furtado (1959). Menos ainda é possível validar a tese de Peláez (1971) de que o suposto apego dos governantes à ortodoxia teria obstaculizado a recuperação da economia brasileira naquele período. Pelo contrário, as políticas monetária, fiscal, creditícia e cambial no período foram ativamente utilizadas para a superação dos efeitos da crise econômica mundial sobre a economia brasileira, bem como para a sustentação de novos pactos políticos firmados pelo governo. Os efeitos econômicos são claros: a partir de 1932, as políticas monetária, fiscal, cambial e creditícia anticíclicas já haviam promovido a recuperação das taxas de crescimento da economia, de modo que o PIB passou a crescer a uma taxa média anual de 6,1\% entre 1932 e 1939. Além disso, na esteira da criação do referido diverso aparato institucional para o fomento da indústria, o PIB industrial, após uma forte contração no ano de 1930, retornou à trajetória de crescimento já no ano seguinte, passando, posteriormente, a crescer a uma taxa média anual superior a 10\% entre 1934 e 1939 (IPEADATA, 2015).

\section{Referências}

ABREU, M. P. Crise, crescimento e modernização autoritária: 1930-1945. In: (Org.). A ordem do progresso: cem anos de política econômica republicana (1889-1989). Rio de Janeiro: Campus, 1990.

ABREU, M. P. O Brasil e a economia mundial: 1930-1945. Rio de Janeiro: Civilização Brasileira, 1999.

BASTOS, P. P. Z. A dependência em progresso: fragilidade financeira, vulnerabilidade comercial e crises cambiais no Brasil (1890-1954). 2001. Tese (Doutorado em Ciências Econômicas) - Programa de Pós-Graduação em Ciências Econômicas, Instituto de Economia, Universidade Estadual de Campinas, Campinas, SP, 2001. 
. Gestão macroeconômica, mudança institucional e revolução burguesa na era Vargas: quando a ortodoxia foi superada? Campinas: IE/ UNICAMP, ago. 2008. (Texto para discussão, n. 146).

Ortodoxia e heterodoxia antes e durante a era Vargas: contribuições para uma economia política da gestão macroeconômica nos anos 1930. Campinas: IE/UNICAMP, jun. 2010a. (Texto para discussão, n. 179).

. Qual era o projeto econômico varguista? Instituto de Economia da UNICAMP, maio 2010b. (Texto para discussão, n. 161).

CANO, W. Crise de 1929: soberania na política econômica e industrialização. In: PRADO, L.C.D. (Org.). Desenvolvimento econômico e crise: ensaios em comemoração aos 80 anos de Maria da Conceição Tavares. Rio de Janeiro: Contraponto; Centro Internacional Celso Furtado, 2012.

CANO, W. Raizes da concentração industrial em São Paulo. 2. ed. São Paulo: Hucitec, 1975.

CORSI, F. L. Estado novo: política externa e projeto nacional. São Paulo: Ed.da Unesp, 2000.

DELFIM NETTO, A. O problema do café no Brasil. São Paulo: Editora da Unesp, 2009.

DRAIBE, S. Rumos e metamorfoses: estado e industrialização no Brasil 1930-1960. Rio de Janeiro: Paz e Terra, 2004.

FAUSTO, B. (Org.). História geral da civilização brasileira: o Brasil Republicano (8). Rio de Janeiro: Editora Bertrand Brasil, v. 8. tomo III, 2006 a.

. Expansão do café e política cafeeira. In: FAUSTO, B. (Org.). História geral da civilização brasileira: o Brasil Republicano. Rio de Janeiro: Bertrand Brasil, 2006b. v. 8. tomo III.

. História concisa do Brasil. 2. ed. São Paulo: Editora da USP, 2011.

. Revolução de 1930: historiografia e história. SP: Companhia das Letras, 1997.

FISHLOW, A. Origens e consequências da substituição de importações no Brasil. In: VERSIANI, F.; BARROS, J. R. (Org.). Formação econômica do Brasil: a experiência da industrialização. São Paulo: Saraiva, 1972.

FONSECA, P. C. D. A ortodoxia posta em questão: a política econômica e a percepção governamental da crise dos anos 30 no Brasil. Ensaios FEE, v. 7, n. 1, p. 125-143, 1986.

. Sobre a intencionalidade da política industrializante do Brasil na década de 1930. $\overline{R e v i s t a}$ de Economia Política, n. 23, v. 1, p. 133-148, 2003.

. Vargas: o capitalismo em construção. São Paulo: Brasiliense, 1989.

FRANCO, G. H. B.; LAGO, L. A. C. O processo econômico: a economia da primeira república, 1889/1930. In: SCHWARCZ, L. M. (Coord.). A abertura para o mundo, 1889-1930. Rio de Janeiro: Objetiva; Madrid: Fundação MAPFRE, 2012. v. 3. (Coleção História do Brasil Nação: 1808-2010). 
FRANCO, G. H.B. Uma nota sobre a política fiscal durante os anos 30. Pesquisa e Planejamento Econômico, v. 15 n. 2, p. 401-418, ago. 1985.

FRITSCH, W. Apogeu e crise na primeira república: 1900-1930. In: ABREU, M. P. (Org.). A ordem do progresso: cem anos de política econômica republicana (1889-1989). Rio de Janeiro: Campus, 1990.

FURTADO, C. Depoimento. In: A Revolução de 30: seminário internacional realizado pelo Centro de Pesquisa e Documentação de História Contemporânea da Fundação Getúlio Vargas. Brasília, DF: Universidade de Brasília, 1982. (Coleção Temas Brasileiros, 54).

. Dialética do Desenvolvimento. Rio de Janeiro: Fundo de Cultura, 1964.

. Formação econômica do Brasil. São Paulo: Companhia Editora Nacional, 1959.

IBGE. Anuário estatístico do Brasil de 1939/40. Ano V. Rio de Janeiro: IBGE, 1941.

IPEADATA. Ipeadata. 2015. Disponível em: < http://www.ipeadata.gov.br/>. Acesso em: 07 jun. 2015.

KERSTENETZKY, C. L. O estado de bem estar social na idade da razão: a reinvenção do estado social no mundo contemporâneo. São Paulo: Campus, 2012.

KOIFMAN, F. (Org.). Presidentes do Brasil (de Deodoro a FHC). Rio de Janeiro: Universidade Estácio de Sá; São Paulo: Associados, 2002. (Projeto presidentes do Brasil).

LOVE, J. O Rio Grande do Sul como fator de instabilidade na república velha. In: FAUSTO, B. (Org.). História geral da civilização brasileira: o Brasil republicano, estruturas de poder e economia (1889-1930). Rio de Janeiro: Bertrand Brasil, 2006a. p. 111-138.

MATTOS, H. A vida política. In: SCHWARCZ, L. M. A abertura para o mundo, 1889-1930. Rio de Janeiro: Objetiva; Madrid: Fundação MAPFRE, 2012. v. 3. (História do Brasil nação: 1808-2010).

NEUHAUS, P. História monetária do Brasil: 1900-1945. Rio de Janeiro: Ibmec, 1975.

PELÁEZ, C. As consequências econômicas da ortodoxia monetária, cambial e fiscal no Brasil entre 1889-1945. Revista Brasileira de Economia, v. 25, n. 3, p. 5-82, 1971.

SCHWARCZ, L. M. (Coord.). A abertura para o mundo, 1889-1930. In: História do Brasil nação: 1808-2010. Rio de Janeiro: Objetiva; Madrid: Fundação MAPFRE, 2012. v. 3.

SILBER, S. Análise da política econômica e do comportamento da economia brasileira durante o período 1929-1939. In: VERSIANI, F.; BARROS, J. R. (Org.). Formação econômica do Brasil: a experiência da industrialização. São Paulo: Saraiva, 1977.

SUZIGAN, W. Industrialização e política econômica: uma interpretação em perspectiva histórica. Pesquisa e Planejamento Econômico, v. 15, n. 2, p. 433-474, 1975.

TAVARES, M. C. Da substituição de importações ao capitalismo financeiro. Rio de Janeiro: Zahar, 1972. 
TRIFFIN, R. The myth and the reality of the so-called gold standard. In: . The evolution of the international monetary system: historical reappraisal and future perspectives. New Jersey: Princeton University Press, 1964. cap. 1.

VAN DER LAAN, C. R.; CUNHA, A. M.; FONSECA, P. C. D. Os pilares institucionais da política cambial e a industrialização nos anos 1930. Revista de Economia Política, v. 32, n. 4, p. 597-614; out./dez. 2012.

VARGAS, G. Plataforma da aliança liberal. In: VARGAS, G. O pensamento político de Getúlio Vargas. Porto Alegre: ALERG E IHGRG, 2004. p. 12-37.

VILLELA, A.; SUZIGAN, W. Política do governo e crescimento da economia brasileira, 18891945. Brasília, DF: Ipea; Inpes, 1973.

Recebido em: 22/08/2013. Aceito em: 27/03/2015. 